\title{
CAVE INVERTEBRATES IN NORTHWESTERN MINAS GERAIS STATE, BRAZIL: ENDEMISM, THREATS AND CONSERVATION PRIORITIES.
}

\author{
JAMSKI NEVRETENČARJI V SEVEROZAHODNEM PREDELU \\ MINAS GERAIS, BRAZILIJA: ENDEMIZEM, OGROŽENOST \\ IN VIDIKI VAROVANJA
}

Matheus Henrique SIMÕES ${ }^{1,2}$, Marconi SOUZA-SILVA ${ }^{3}$ \& Rodrigo Lopes FERREIRA ${ }^{1}$.

\begin{abstract}
UDC 551.435.84:502.17(815.1)
Matheus Henrique Simões, Marconi Souza-Silva \& Rodrigo Lopes Ferreira: Cave invertebrates in northwestern Minas Gerais State Brazil: endemism, threats and conservation priorities

Due to their high economic value, karstic areas and caves have been affected for decades in Brazil. Accordingly, such systems have been receiving the attention of managers, environmental agencies and researchers, especially in recent years. The present study collected information regarding the cave invertebrate fauna of the Northwest region of Minas Gerais, Brazil, such as species richness and endemisms, besides the impacts and threats occurring in these environments, identifying caves and more vulnerable areas and proposing conservation actions. Three caves were identified as a priority for conservation: Lagoa Rica cave in Paracatu, and Lapa Nova and Lapa da Delza caves in Vazante. Another three areas were considered in need of conservation actions: regions of Arinos, Paracatu and Cabeceira Grande/Unaí. The main threat found in the area was the conversion of forests into pastures for cattle breeding, registered in the surroundings of $85 \%$ of the caves. The main recommendations were the recuperation of the surroundings, awareness raising of the population and biospeleological inventories in other caves of the area. The studied caves were very heterogeneous, presenting unique characteristics. Thus, the study of the highest possible number of caves of the region of interest is always recommended, to aid in conservation and action plans for cave fauna.
\end{abstract}

Key words: invertebrates, caves, conservation, endemisms.

\begin{abstract}
Izvleček
UDK 551.435.84:502.17(815.1)

Matheus Henrique Simões, Marconi Souza-Silva \& Rodrigo Lopes Ferreira: Jamski nevretenčarji v severozahodnem predelu Minas Gerais, Brazilija: endemizem, ogroženost in vidiki varovanja

Kraška področja in jame v Braziliji so zaradi visoke gospodarske vrednosti že desetletja prizadeta. Posledično so, zlasti v zadnjih letih, pritegnila pozornost upravljalcev, okoljskih agencij in raziskovalcev. V pričujoči študiji so zbrani podatki o jamski favni severozahodnega območja Minas Gerais v Braziliji s poudarkom na bogastvu vrst in endemizmu, poleg ugotovljenih vplivov in nevarnosti, ki se pojavljajo $\mathrm{v}$ teh okoljih ter jam in drugih ranljivih predelov, za katere predlagamo ukrepe za njihovo ohranitev. Tri jame so bile opredeljene kot prednostne za ohranitev: jama Lagoa Rica v Paracatu in jami Lapa Nova in Lapa da Delza v Vazante. Poleg tega so bile prepoznane tri regije, kjer naj bi se izvajali ukrepi varovanja: Arinos, Paracatu in Cabeceira Grande/Unaí. Največja grožnja na teh območjih, kjer je registriranih $85 \%$ jam, je izsekavanje gozdov in sprememba v pašnike za vzgojo govedoreje. Glavna priporočila so zaščita področja, ozaveščanje prebivalstva in biospeleološke raziskave $\mathrm{v}$ drugih jamah na proučevanem območju. Vse raziskovane jame so heterogene, $\mathrm{z}$ edinstvenimi lastnostmi. Priporočene so raziskave $\mathrm{v}$ čim večjem številu jam, kot dodana vrednost pri načrtih za ohranjanje in varovanje jamske favne.
\end{abstract}

Ključne besede: nevretenčarji, jame, varovanje, endemizem.

\footnotetext{
${ }^{1}$ Laboratório de Ecologia Subterrânea, Setor de Zoologia/Departamento de Biologia, Universidade Federal de Lavras, Cx Postal 3037, Campus Universitário, CEP 37200-000 Lavras, Minas Gerais, Brasil, e-mail: drops@dbi.ufla.com.br

${ }^{2}$ Programa de Pós-Graduação em Ecologia Aplicada, Departamento de Biologia, Universidade Federal de Lavras, Cx Postal 37, Campus Universitário, CEP 37200 000, Lavras, Minas Gerais, Brasil, e-mail: matsimoes@hotmail.com

${ }^{3}$ Núcleo de Pesquisas em Ciências Biológicas (www.npcbio.org)/Centro Universitário de Lavras (UNILAVRAS),

e-mail:marconisouza@unilavras.edu.bra
}

Received/Prejeto: 18.02 .2013 


\section{INTRODUCTION}

Caves are habitats for several species that use them for the most diverse purposes (Culver \& Pipan 2009). The troglobites, a strictly cave species, stand out in function of the frequent evolutionary modifications of morphological, physiological and behavioral character that make them highly specialized to live in these environments (Culver \& Wilkens 2000). As such, caves are places of great importance for the study of evolutionary processes moulded by the selective pressures typical of these environments, such as permanent absence of light, shortage of food resources, high moisture/humidity and constant temperatures, among others (Culver \& Pipan 2009).

Many troglobitic species occur in a single cave or a small group of caves. Once these environments have been extensively altered, especially in recent decades, it is possible that many species have disappeared without even having been described (Elliott 2000). Furthermore, caves are important for the maintenance of the ecosystems where they are inserted, because they frequently possess drains that supply the surface and are shelters of species that provide recognized ecological services to the external ecosystem, as for instance, the bats (Elliott 2000).

Although the importance of the subterranean habitats is evident, caves have been threatened over the years by anthropic interventions (Watson et al. 1997). These interventions are resulting in negative effects, such as hydric resource pollution and reduction, changes in the hydrologic regime, habitat alterations and local species population decline, among others (Gillieson \& Thurgate 1999; Parise \& Pascali 2003; De Waele \& Follesa 2003; Neill et al. 2004; Van Beynen et al. 2007). Given these threats, karstic areas and caves are receiving the attention of managers, environmental agencies and researchers, mainly in recent decades, due to the great importance of those areas to science (geology, paleontology, archeology and biology), as well as to human values (spiritual, religious, aesthetic, recreational and educational) (Watson et al. 1997).

Due to the socioeconomic importance of karstic areas and the consumption increase of natural goods and products it is unlikely that some caves do not come to be affected, even those that present rare species (Gibert \& Deharveng 2002). As such, to recognize locals with conservation priority is an important step for the creation of preserved areas and maintenance of the subterranean biodiversity.

In Brazil, studies with the objective of proposing areas that need emergency action for subterranean fauna conservation have been conducted, especially in recent years (Souza-Silva 2008; Zampaulo 2010; Bento 2011; Souza 2012). Such studies are based mainly on three aspects: (I) presence of troglobite species considered relevant in function of the "evolutionary status", knowledge inadequacy, restricted distribution and fragility facing random habitat alteration events (Culver \& Wilkens 2000; Culver \& Pipan 2009), (II) species richness, by enabling complex ecological interactions and processes (Ferreira 2004) and (III) the conservational state of the cave surroundings and interiors, which can reveal the impact degree and the threats imposed to the fauna (Souza-Silva 2008).

Recently a National Action Plan was published (PAN) for the conservation of the speleological patrimony in the karstic areas of the São Francisco river basin (Cavalcanti et al. 2012), the third largest hydrographic basin and one of the most important in Brazil. Among the three karstic areas within the scope of PAN, the Region I, located in Middle San Francisco Basin (karstic areas of the Paranoá Group, Bambuí Group and Vazante Formation), can be considered the most lacking in studies related to the cave fauna. The few works regarding the subterranean fauna were only made at one cave, Lapa Nova, located in the municipal district of Vazante, state of Minas Gerais (Pellegrini \& Ferreira 2012a, b; Souza \& Ferreira 2012). As such, the present study gathered information of the cave invertebrate fauna, such as species richness and endemisms, and the impacts and the threats occurring to the environment, identifying caves and more vulnerable areas and proposing conservation actions.

\section{MATERIALS AND METHODS}

\section{STUDY AREA}

The study was carried out in 47 caves distributed in eight municipal districts of the Northwest area of Minas Gerais, Brazil. The caves are inserted in Region I of the
National Action Plan for the conservation of the speleological patrimony in the karstic areas of the São Francisco river basin (PAN Caves of São Francisco) (Cavalcanti et al. 2012) (Fig. 1). 


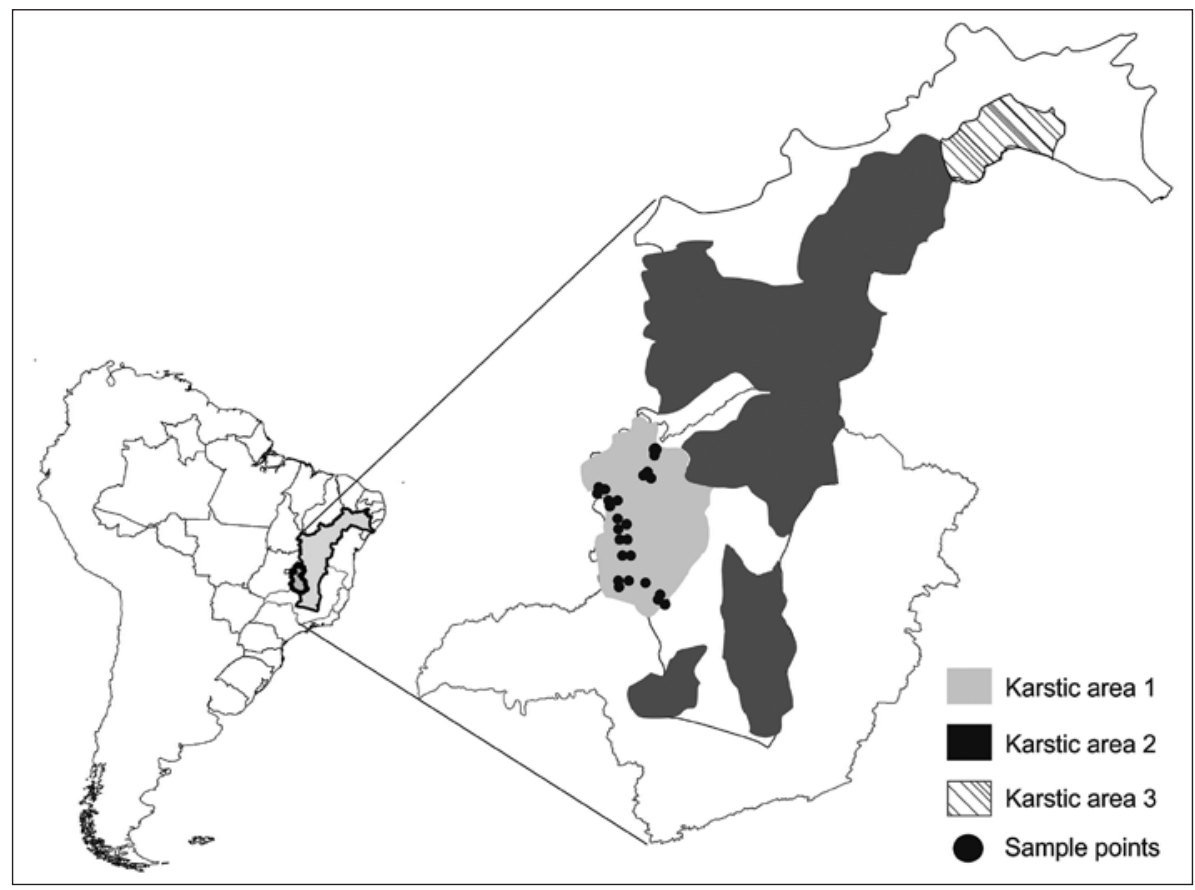

Fig. 1: Map of South America highlighting Brazil, Rio San Francisco hydrographic basin, and the state of Minas Gerais. Inside the San Francisco basin the karstic areas inserted in PAN San Francisco are highlighted. The caves of the present study are distributed through eight municipal districts of the Northwest area of Minas Gerais, belonging to the karstic area 1 of PAN Caves of São Francisco.

\section{INVERTEBRATE SAMPLING}

The collection of invertebrates was conducted through active searches throughout whole cave with the aid of tweezers, brushes and hand nets. During the collections, organic deposits were prioritized (plant debris deposits, carcasses, guano, etc.) and micro-habitats (under stones, moist soil, openings, speleothems, etc.). All of the collected specimens were conditioned in vials with $70 \%$ alcohol. The collection team was always composed of four biologists with experience in speleology and collection of invertebrates in caves, as recommended by Weinstein \& Slaney (1995).

All of the organisms were identified until the lowest taxonomic level accessible and separated into morphospecies, as in other works (Souza-Silva 2011b; Oliver \& Beattie 1996; Derraik et al. 2002; Ward \& Stanley 2004; Derraik et al. 2010). All of the specimens are deposited in the subterranean invertebrate collection of Lavras (ISLA), at the Federal University of Lavras (UFLA).

The identification, in the specimens, of "troglomorphic" traits, was used for classification of potentially troglobitic species. Such characteristics vary among the groups, but are frequently represented by the reduction of pigmentation, reduction of ocular structures and appendage elongation (Culver \& Wilkens 2000).

\section{CAVE RATING TOOLS}

The definition of the priority areas for conservation was based on the overlapping of the biological relevance, troglobitic species presence and impact degree in the caves as described below (modified from Souza-Silva 2008).

\section{Biological relevance}

The biological relevance categories were defined as extreme, high, medium and low, based on the total and relative species richness. The relative species richness in each cave was calculated through the ratio among the total richness, the horizontal projection of the cave and extension of the entrance (Souza-Silva 2008).

The highest value obtained for richness and relative richness was divided by four. Thus we obtained four categories of total and relative richness (extreme, high, medium and low) with intervals of number of species.

For the categorization of the biological relevance of the caves, weights were attributed to the total and relative richness categories. Caves with extreme total richness received Weight 8; high total richness Weight 6; medium total richness Weight 4 and low total richness Weight 2. Caves with extreme relative richness received Weight 4; high relative richness Weight 3 , medium relative richness Weight 2 and low relative richness Weight 1.

It was defined that the total richness should receive the double the weight of the relative richness in function of the real and direct importance of the absolute number of species, as a parameter of preservation of a given system. In case only the relative richness was used, one would run the risk of preserving reduced caves, but with a relatively high number of species to the detriment of extensive caves and with high absolute richness (SouzaSilva 2008).

The biological relevance for each cave was determined through the sum of the weights of the total and relative richness for each cave. The highest biological 
relevance served as a basis for the inclusion of the caves in the categories of extreme, high, medium and low final biological relevance. Caves with extreme biological relevance received Weight 4; high final biological relevance received Weight 3 , medium final biological relevance received weight 2 and low final biological relevance received Weight 1.

\section{Troglomorphic species categories}

The highest values of troglomorphic species richness found served as the basis for classification of the caves as extreme (Weight 4), high (Weight 3), medium (Weight 2) and low (Weight 1) troglomorphic species richness.

\section{Characterization of impacts}

Environmental impacts were defined for each cave in function of the presence or absence of alterations in their internal and external environments. The surveyed alterations were classified in relation to uses and impacts. Tourism and religious activities were considered uses, impacts being trampling, illumination, and the consequent alterations by these activities.

From the identification of the impacts in the caves we proceeded to a second analysis concerning the magnitude of these impacts that can cause alterations in the communities. Such analysis considered from impacts that could cause minimum alterations to those that would considerably affect the cave fauna.
In the impact definitions, three types of modifications were considered (depletion, enrichment and alteration). The first modification type is that which can lead to depletion, in other words, the reduction of trophic resources or the fauna in function of the anthropic activities and the second type, the alterations that lead to the enrichment in the availability of organic resources for the fauna. The third type of modification is that which modifies, in space and time, the physical structure of habitats or micro-habitats in the caves, called alteration impacts. It is emphasized that the same impact can lead to more than one type of these three modifications.

For attribution of the weights, the impacts were classified according to the potential, into intense (potentially the cause of intense alterations in the fauna - Weight 2) or tenuous (potentially the cause of reduced alterations on the fauna - Weight 1). A second classification added to the impact analysis the deals with their permanence. The permanence refers to the period of time the impact persists. Thus, the impacts were considered of short (Weight 1) or continuous duration (Weight 3 ). We opted for a weight attribution three times higher for continuous impacts for the fact that the continuity of the impacts can cause much greater damage than those of short duration. The last impact classification refers to the range of the impact. Punctual impacts received Weight 1 , while those that occur over a wide range (systemic impacts) received Weight 2. The impacts that presented more than

Tab. 1: Valuation of the impacts to the caves. D: depletion, E: enrichment, A: alteration, I: intense; T: tenuous; CD: continuous duration; SD: short duration; GI: general impact; LI: localized impact; W: weigh of impacts; FIW: final impact weights $\left(=\Sigma w_{\text {potencial }}+\sum w_{p e n}\right.$ $\left.+\Sigma w_{\text {range }}\right) ; *$ impacts inside the caves (Modified from Souza-Silva 2008).

\begin{tabular}{|c|c|c|c|c|c|c|c|c|}
\hline Impacts & Modification & Potential & $W$ & Permanence & $W$ & Range & $W$ & FIW \\
\hline Mining & $D+A$ & I & $2+2$ & CD & 3 & Gl & 2 & 9 \\
\hline Garbage & $E+A$ & I & $2+2$ & $C D$ & 3 & Gl & 2 & 9 \\
\hline Bare soil & A & I & 2 & $C D$ & 3 & $\mathrm{LI}$ & 1 & 6 \\
\hline Roads surroundings & $A$ & $\mathrm{~T}$ & 1 & CD & 3 & $\mathrm{LI}$ & 1 & 5 \\
\hline Trail & $A$ & $\mathrm{~T}$ & 1 & CD & 1 & $\mathrm{LI}$ & 1 & 3 \\
\hline Siltation & $A$ & I & 2 & CD & 3 & $\mathrm{LI}$ & 1 & 6 \\
\hline Area burned & $A$ & I & 2 & $\mathrm{SD}$ & 1 & $\mathrm{LI}$ & 1 & 4 \\
\hline Deforestation & $\mathrm{D}$ & $\mathrm{T}$ & 1 & SD & 1 & GI & 2 & 4 \\
\hline Impermeability of the soil & $A$ & I & 2 & $C D$ & 3 & $\mathrm{LI}$ & 1 & 6 \\
\hline Livestock & $A$ & $\mathrm{~T}$ & 1 & $C D$ & 3 & $\mathrm{LI}$ & 1 & 5 \\
\hline${ }^{*}$ Destruction of speleothems & A & $\mathrm{T}$ & 1 & CD & 1 & $\mathrm{LI}$ & 1 & 3 \\
\hline *Silting of drainage & $D+A$ & I & 2 & CD & 3 & $\mathrm{LI}$ & 1 & 6 \\
\hline${ }^{*}$ Graffiti & A & $\mathrm{T}$ & 1 & SD & 1 & $\mathrm{LI}$ & 1 & 3 \\
\hline * trampling & A & I & 2 & $C D$ & 3 & Gl & 2 & 7 \\
\hline${ }^{*}$ Constructions & $A$ & 1 & 2 & SD & 1 & $\mathrm{LI}$ & 1 & 4 \\
\hline *Bonfires & A & $\mathrm{T}$ & 1 & CD & 1 & $\mathrm{LI}$ & 1 & 3 \\
\hline *Burning tire & $D+A$ & I & $2+2$ & CD & 1 & $\mathrm{LI}$ & 1 & 6 \\
\hline
\end{tabular}


one of the three alterations (depletion, enrichment or alteration) had the intensity weights added.

Tab. 1 shows some examples of impacts that were registered for the interior and surroundings of the caves and the weights attributed to each one. Note that the final weight can vary among the caves, because the same impact can present intensity, permanence and different range for each cave.

The categorization of the caves regarding the impact degree was conducted starting from the sum of the values obtained in each cave. The highest sum of impacts served as the basis for the separation of the caves regarding the degree of impacts into extreme (Weight 4), high (Weight 3), medium (Weight 2) and low (Weight 1).

\section{Vulnerability and priority caves for conservation}

The degree of vulnerability of the invertebrate communities of each cave was obtained from the sum of the weights of the final biological relevance, richness of troglomorphic species and the impacts present in each cave. The highest vulnerability value was used for the inclusion of the caves in the vulnerability categories extreme, high, medium and low.

Caves classified as extreme vulnerability were considered as priority caves for conservation. Regions with caves with high vulnerability were highlighted as areas of secondary priority and that need some conservation action.

\section{RESULTS}

A total of 1,348 invertebrate species was registered distributed in at least 170 families. The average richness was $63( \pm 29)$ species. The Lapa Nova cave presented the highest richness ( 155 species) and the V01 cave presented the lowest species richness (15 species) (Tab. 2).

Among the 47 caves, $4.26 \%$ were classified as of extreme total richness (117-155 species), $19.15 \%$ as high (78-116 species), 59.57\% medium (39-77 species) and $17.02 \%$ low (less than 39 species) (Tab. 2). The highest relative richness registered was at the Gruta Nove cave (3.822) and lowest in the Lapa Nova cave (0.001). Thus, $2.13 \%$ of the caves presented extreme (2.868 to 3.822 ), $2.13 \%$ high (1.913 to 2.867 ), $8.51 \%$ medium ( 0.956 to 1.912 ) and $87.23 \%$ low relative richness (under 0.956 ) (Tab. 2).

The highest sum obtained through the weights attributed to the caves starting from the total and relative richness classifications was nine. As such, $25.53 \%$ of the caves were classified as with extreme (7 to 9), $57.45 \%$ high (5 or 6 ) and $17.02 \%$ medium ( 3 or 4 ) biological relevance (Tab. 2). No cave presented low biological relevance.

Thirty six troglomorphic species were distributed throughout 19 caves, all with at least one endemic species, representing $80 \%$ of endemic species for a single cavity. Some troglomorphic species are presented in Fig. 2. The caves with the highest troglomorphic species richness were the Lagoa Rica cave, in Paracatu, with seven species and the Lapa Nova cave, in Vazante, with six species. Therefore, $4.26 \%$ of the caves were classified as of extreme (6 or 7 species), 2.13\% high (4 or 5 species), $21.28 \%$ medium ( 2 or 3 species) and $72.34 \%$ low troglomorphic species richness ( 0 or 1 species) (Tab. 2).
The main use of the surroundings was the pastures, registered in $85.11 \%$ of the cave surroundings. The main use of the interior was tourist visitation, observed in $23.4 \%$ of the caves. The main impact found in the cave surroundings were trails, registered in $72.34 \%$ of the caves surroundings. The main impact observed inside the caves was the trampling, registered in $38.3 \%$ of the caves. Mining was considered as the main potential impact in the surroundings, being likely to occur in the future in $34 \%$ of the caves. The pollution of water bodies stood out as the main impact inside the caves, being likely in $27.6 \%$ of the caves. Some impacts are presented in Fig. 3.

The highest sum of the weights attributed to the caves regarding the observed impacts was registered for the Lapa do Campo de Futebol, located in the municipal district of Matutina (61), it being the only cave with extreme impact degree (46 to 61 ). $12.77 \%$ of the caves presented high (31 to 45 ), $38.3 \%$ medium (17 to 30 ) and $46.8 \%$ of the caves presented low degree of impact (below 16) (Tab. 2).

The highest sum of the weights attributed to the three items considered in this study regarding importance for cave conservation (biological relevance, troglobitic species presence and conservation state) was 11, registered for the Lapa Nova, municipal district of Vazante. As such, 6.38\% (three caves) of the caves were classified as those of extreme vulnerability (9 to 11), $68.09 \%$ as high (6 to 8 ) and $25.53 \%$ of medium vulnerability (3 to 5). No cave presented low vulnerability (below 3) (Tab. 2).

The priority caves for conservation were the Lagoa Rica cave (Paracatu municipality), Lapa Nova cave and 
Tab. 2: List of the caves studied in the municipal districts of the Northwest area of Minas Gerais, Brazil, between the years 2009 and 2011. Location in UTM (X, Y, Z), total number of species (S), classification as to total number of species (SC), relative richness (RR), classification as to the relative richness $(R R C)$, biological relevance (BR), troglomorphic species richness $(R T)$, classification as to the troglomorphic species richness (RTC), degrees of impact (DI), vulnerability $(V)$, extreme (E), high (A), medium (M) and low (B), presence of water (PW) (R: rivers, P: pools; PP: phreatic pounds; D: dry).

\begin{tabular}{|c|c|c|c|c|c|c|c|c|c|c|c|c|c|c|}
\hline Municipalities & Caves & $x$ & $Y$ & $Z$ & $P W$ & $S$ & SC & $R R$ & $R R C$ & $B R$ & $R T$ & RTC & $\mathrm{DI}$ & V \\
\hline Arinos & Camila & 353310 & 8240506 & $23 \mathrm{~L}$ & $\mathrm{R}$ & 115 & H & 0.192 & L & $E$ & 2 & M & L & $\mathrm{H}$ \\
\hline Arinos & Capa & 357713 & 8236358 & $23 \mathrm{~L}$ & $\mathrm{R}$ & 113 & H & 0.014 & L & $\mathrm{E}$ & 0 & L & L & $\mathrm{H}$ \\
\hline Arinos & Marcela & 354261 & 8240358 & $23 \mathrm{~L}$ & $R$ & 94 & $\mathrm{H}$ & 0.002 & L & E & 0 & L & M & $\mathrm{H}$ \\
\hline Arinos & Suindara & 354162 & 8240098 & $23 \mathrm{~L}$ & D & 55 & M & 0.021 & L & H & 0 & L & M & $\mathrm{H}$ \\
\hline Arinos & Salobo & 369279 & 8287176 & $23 \mathrm{~L}$ & $P$ & 50 & M & 0.188 & L & H & 2 & M & M & $\mathrm{H}$ \\
\hline Arinos & Taquaril & 369401 & 8295327 & $23 \mathrm{~L}$ & $\mathrm{R}$ & 78 & $\mathrm{H}$ & 0.104 & L & E & 1 & L & L & $\mathrm{H}$ \\
\hline Arinos & Velho Juca & 354106 & 8240266 & $23 \mathrm{~L}$ & D & 46 & M & 0.093 & L & H & 3 & M & M & $\mathrm{H}$ \\
\hline Cabeceira Grande & Caidô & 259885 & 8206642 & $23 \mathrm{~K}$ & D & 70 & M & 0.006 & L & H & 1 & L & M & $\mathrm{H}$ \\
\hline Cabeceira Grande & Porco Espinho & 257418 & 8206250 & $23 \mathrm{~K}$ & D & 35 & L & 0.529 & L & M & 0 & L & L & M \\
\hline João Pinheiro & Sapecado & 350114 & 8015342 & $23 \mathrm{~K}$ & D & 26 & L & 0.867 & L & M & 0 & L & L & M \\
\hline João Pinheiro & Tauá & 350312 & 8015352 & $23 \mathrm{~K}$ & D & 22 & L & 0.055 & L & M & 0 & L & L & M \\
\hline Matutina & Cachoeira & 399044 & 7874960 & $23 \mathrm{~K}$ & $P$ & 61 & M & 0.229 & L & H & 0 & L & M & $\mathrm{H}$ \\
\hline Matutina & Nove & 399102 & 7874933 & $23 \mathrm{~K}$ & D & 48 & M & 3.822 & E & E & 0 & L & $H$ & $\mathrm{H}$ \\
\hline Matutina & Campo de Futebol & 398585 & 7874853 & $23 \mathrm{~K}$ & $D$ & 42 & M & 0.112 & L & H & 0 & L & E & $\mathrm{H}$ \\
\hline Paracatu & Lagoa Rica & 309267 & 8102836 & $23 \mathrm{~K}$ & PP & 55 & M & 0.055 & L & H & 7 & $E$ & H & $E$ \\
\hline Paracatu & Tamanduá II & 311508 & 8070394 & $23 \mathrm{~K}$ & D & 41 & M & 0.539 & L & H & 0 & L & M & $\mathrm{H}$ \\
\hline Paracatu & Cava & 297248 & 8132338 & $23 \mathrm{~K}$ & D & 48 & M & 0.383 & L & H & 0 & L & M & $\mathrm{H}$ \\
\hline Paracatu & Santa Fé & 297342 & 8133601 & $23 \mathrm{~K}$ & D & 30 & L & 0.018 & L & M & 0 & L & H & $\mathrm{H}$ \\
\hline Paracatu & Brocotó & 308134 & 8083657 & $23 \mathrm{~K}$ & D & 72 & M & 0.533 & L & H & 0 & L & M & $\mathrm{H}$ \\
\hline Paracatu & Brocotó II & 308165 & 8083812 & $23 \mathrm{~K}$ & D & 73 & M & 0.243 & L & H & 0 & L & M & H \\
\hline Paracatu & Santo Antônio & 306536 & 8105656 & $23 \mathrm{~K}$ & $P$ & 51 & M & 0.055 & L & H & 0 & L & $H$ & $\mathrm{H}$ \\
\hline Presidente Olegário & Caieira & 385073 & 7974405 & $23 \mathrm{~K}$ & D & 61 & M & 0.014 & L & H & 0 & L & L & M \\
\hline Presidente Olegário & Juruva & 385747 & 7973888 & $23 \mathrm{~K}$ & R & 112 & $\mathrm{H}$ & 0.030 & L & E & 1 & L & L & $\mathrm{H}$ \\
\hline Presidente Olegário & Vereda da Palha & 380964 & 7981211 & $23 \mathrm{~K}$ & $\mathrm{R}$ & 119 & E & 0.034 & L & E & 1 & L & L & $\mathrm{H}$ \\
\hline Unaí & Abriguinho & 256233 & 8206485 & $23 \mathrm{~K}$ & D & 34 & L & 0.654 & L & M & 0 & L & L & M \\
\hline Unaí & Barth Cave & 279196 & 8183910 & $23 \mathrm{~K}$ & D & 47 & M & 0.021 & L & H & 1 & L & M & $\mathrm{H}$ \\
\hline Unaí & Cachoeira do Queimado & 251574 & 8205653 & $23 \mathrm{~K}$ & D & 57 & M & 0.007 & L & H & 2 & M & M & $\mathrm{H}$ \\
\hline Unaí & Encosta & 255335 & 8206050 & $23 \mathrm{~K}$ & D & 52 & M & 0.650 & L & H & 0 & L & L & M \\
\hline Unaí & Mata dos Paulista & 278976 & 8183510 & $23 \mathrm{~K}$ & $\mathrm{R}$ & 64 & M & 1.422 & M & $\mathrm{H}$ & 0 & L & L & M \\
\hline Unaí & Frangas & 279221 & 8183417 & $23 \mathrm{~K}$ & D & 41 & M & 1.051 & M & H & 0 & L & L & M \\
\hline Unaí & Deus Me Livre & 279976 & 8182900 & $23 \mathrm{~K}$ & D & 106 & H & 0.236 & L & E & 0 & L & L & $\mathrm{H}$ \\
\hline Unaí & Rio Preto & 259263 & 8205827 & $23 \mathrm{~K}$ & D & 56 & M & 0.320 & L & H & 2 & M & L & $\mathrm{H}$ \\
\hline Unaí & Malhadinha & 257965 & 8206112 & $23 \mathrm{~K}$ & D & 108 & $\mathrm{H}$ & 0.311 & L & $E$ & 3 & M & L & $\mathrm{H}$ \\
\hline Unaí & Sapezal & 297937 & 8141547 & $23 \mathrm{~K}$ & $P$ & 71 & $\mathrm{H}$ & 0.041 & L & E & 0 & L & L & $\mathrm{H}$ \\
\hline Vazante & Abrigo da Escarpa & 307964 & 8016869 & $23 \mathrm{~K}$ & D & 36 & L & 0.900 & L & M & 0 & L & M & M \\
\hline Vazante & Escarpa & 307911 & 8016928 & $23 \mathrm{~K}$ & D & 62 & M & 0.332 & L & H & 0 & L & M & $\mathrm{H}$ \\
\hline Vazante & Urtigas & 308192 & 8017657 & $23 \mathrm{~K}$ & D & 70 & M & 0.006 & L & M & 2 & M & M & H \\
\hline Vazante & Urubus & 307785 & 8016598 & $23 \mathrm{~K}$ & D & 93 & $\mathrm{H}$ & 0.063 & L & $\mathrm{E}$ & 3 & M & L & $\mathrm{H}$ \\
\hline Vazante & Não Cadastrada & 308230 & 8017482 & $23 \mathrm{~K}$ & D & 49 & M & 1.332 & M & H & 1 & L & M & $\mathrm{H}$ \\
\hline Vazante & V01 & 306704 & 8017075 & $23 \mathrm{~K}$ & D & 15 & L & 1.500 & M & M & 0 & L & L & M \\
\hline Vazante & V02 & 306618 & 8017108 & $23 \mathrm{~K}$ & $D$ & 37 & L & 2.467 & A & H & 2 & M & L & $\mathrm{H}$ \\
\hline Vazante & Delza & 298146 & 8010447 & $23 \mathrm{~K}$ & PP & 46 & M & 0.008 & L & H & 5 & A & $H$ & $E$ \\
\hline Vazante & Mata Velha & 299617 & 8007387 & $23 \mathrm{~K}$ & $P$ & 61 & M & 0.054 & L & $\mathrm{H}$ & 0 & L & L & M \\
\hline Vazante & Guardião Severino & 300039 & 8010088 & $23 \mathrm{~K}$ & $D$ & 47 & M & 0.063 & L & $\mathrm{H}$ & 0 & L & L & M \\
\hline Vazante & Lapa Nova & 299765 & 8010652 & $23 \mathrm{~K}$ & PP & 155 & E & 0.001 & L & E & 6 & $E$ & H & $E$ \\
\hline Vazante & Lapa Nova II & 299691 & 8010585 & $23 \mathrm{~K}$ & $\mathrm{D}$ & 55 & M & 0.020 & L & H & 3 & M & M & $\mathrm{H}$ \\
\hline Vazante & Sumidouro da Vaca Morta & 306446 & 8016811 & $23 \mathrm{~K}$ & D & 72 & M & 0.639 & L & H & 0 & L & M & $\mathrm{H}$ \\
\hline
\end{tabular}



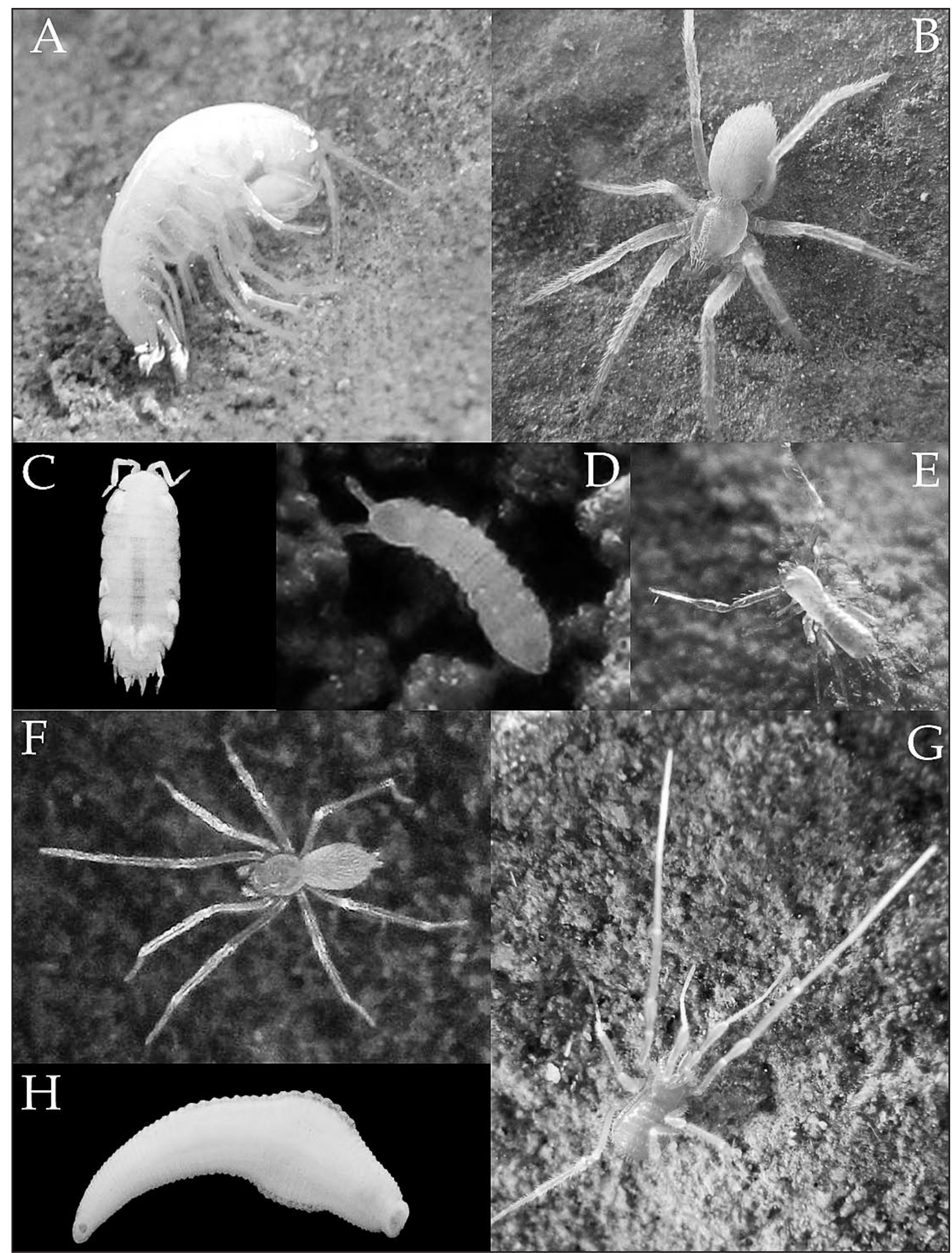

Fig. 2: Examples of troglomorphic species recorded in the Northwest region of the state of Minas Gerais, Brazil. A: Hyallela veredae (Hyallelidae). (Endemic to Vereda da Palha cave), B) Lygromma sp. (Prodidomidae) (Endemic to Cachoeira do Queimado cave); C) Trichorhina sp. (Endemic Camilo cave); D) Acherontides sp. and E) Chthoniidae sp. (Endemic to region of Vazante), F) Tetrablemmidae sp. and G) Speleoleptes sp. (Endemic Lagoa Rica cave), H) Hirudinea sp. (Endemic to Salobo cave). 


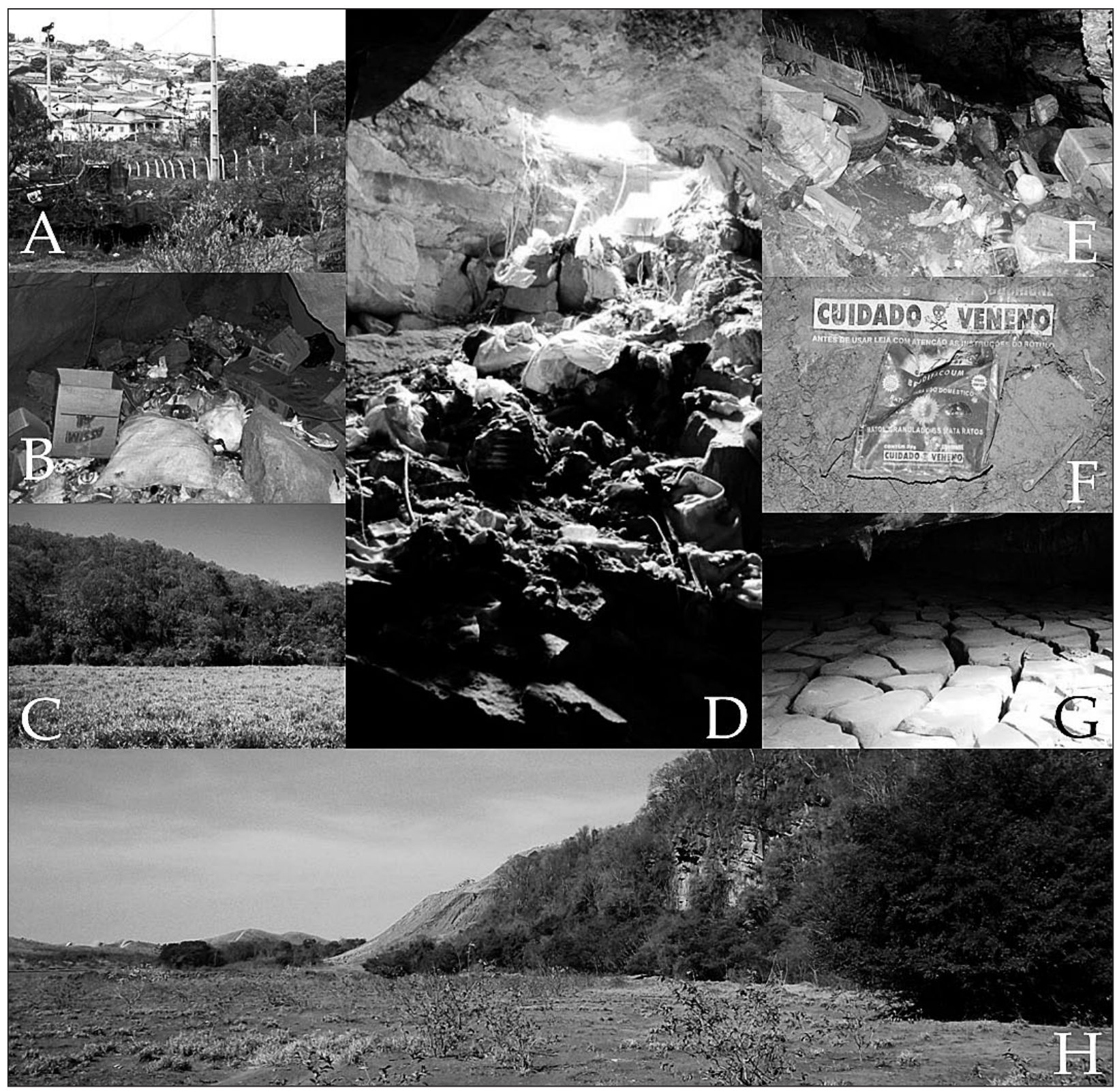

Fig. 3: Some impacts found in the surroundings and interior of the caves studied in the Northwest of the state of Minas Gerais, Brazil, between the years 2009 and 2011: A) Urban district on a cavity (Matutina); B) Discard of organic and veterinary trash (Paracatu); C) Removal of the external vegetation in the area of the surroundings (Paracatu); D) Discard of organic and veterinary trash (Paracatu); E) Discards of urban trash (Vazante); F) Discard of toxic waste (Paracatu); G) Silting of the cave by mining tailings; $H$ ) silting of the surrounding area by mining tailings (Vazante).

Delza cave, (both located in Vazante municipality) (Fig. 4, Tab. 3). Three regions were defined as priority for conservation: (1) the region of Arinos, (2) Cabeceira Grande and Unaí and (3) Paracatu (Fig. 4, Tab. 3). Table 3 summarizes the recommendations for the priority caves for conservation and the areas with need of conservation action, as well as the criteria used for indication. 


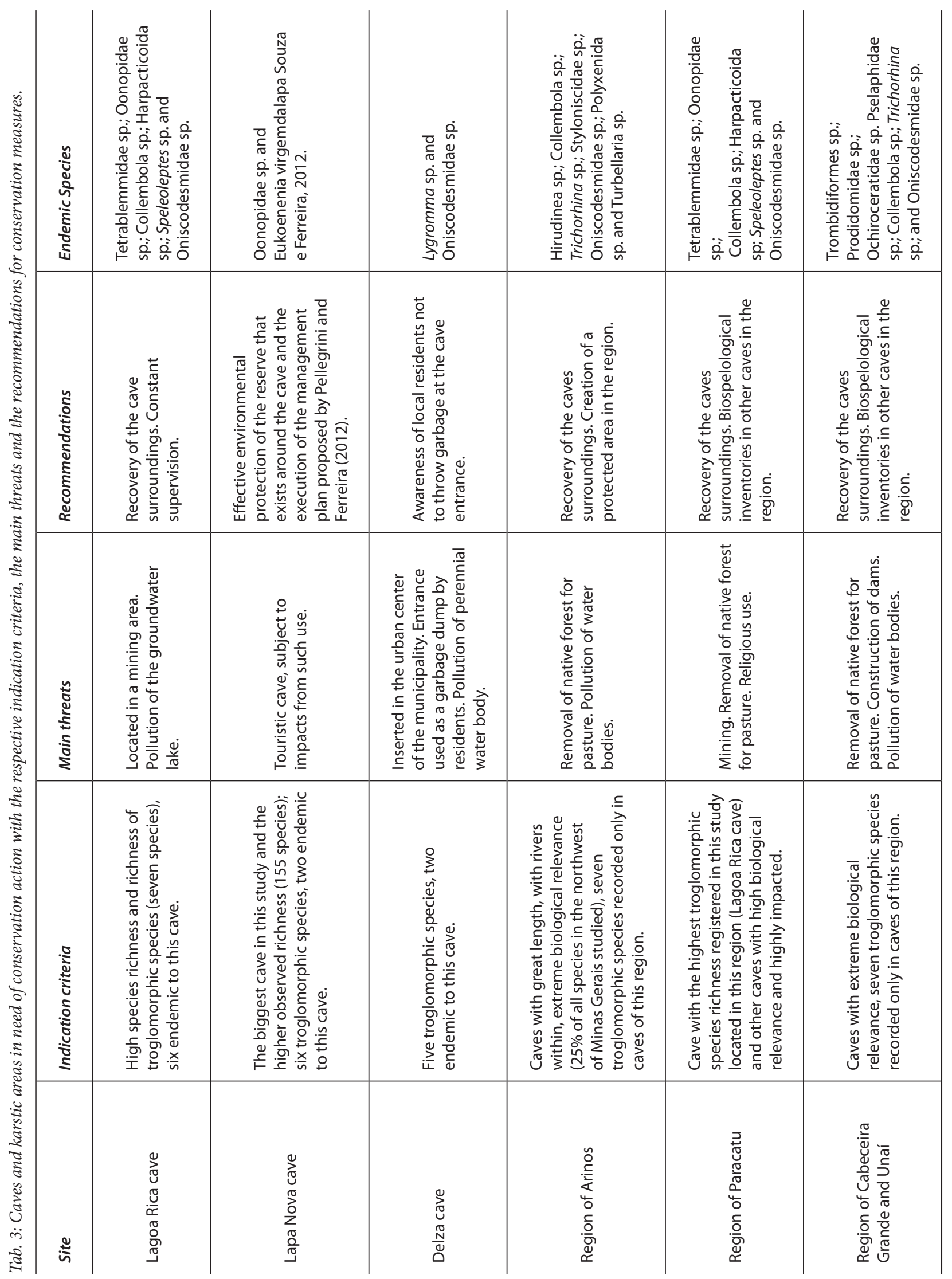




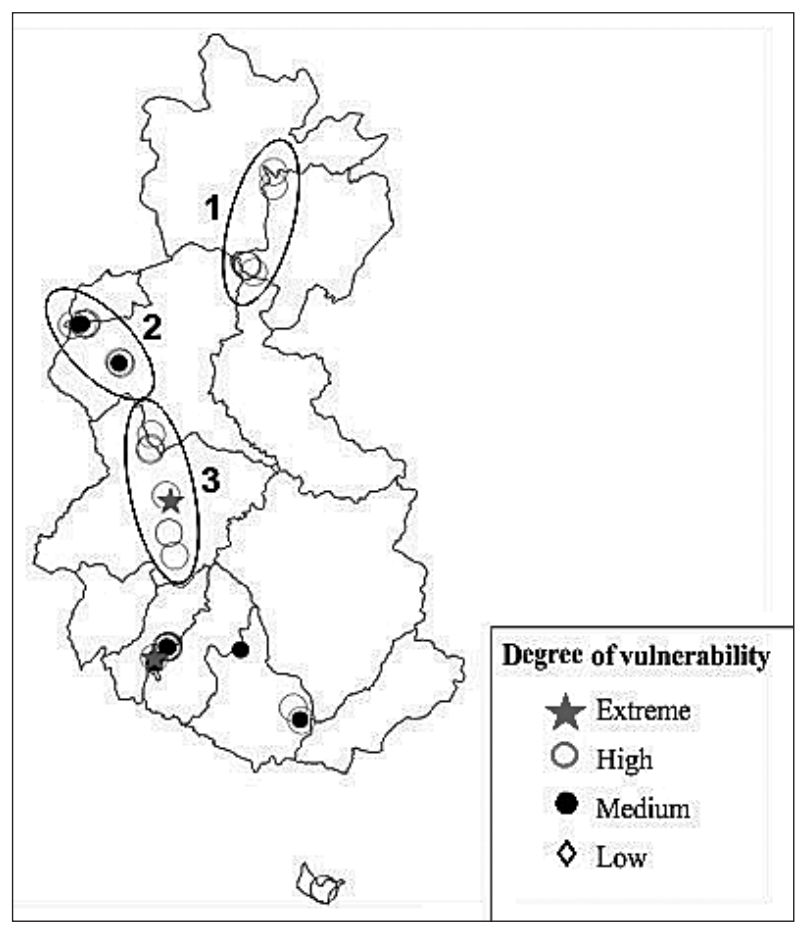

Fig. 4: Distribution map of the caves sampled in the Northwest area of the state of Minas Gerais, Brazil, between the years 2009 to 2011, and their respective classifications as to the vulnerability. The figure highlights the priority caves for conservation (red stars), as well as the regions in need of conservation actions (ellipses). 1: Region of Arinos, 2: Region of Cabeceira Grande and Unai and 3: Region of Paracatu.

\section{DISCUSSION}

\section{BIOLOGICAL RELEVANCE AND ENDEMISMS}

Many studies regarding the subterranean fauna have been conducted in different regions of Brazil (Bento 2011; Bernardi et al. 2012; Cordeiro 2008; Ferreira 2004; Ferreira \& Horta 2001; Ferreira et al. 2009; Ferreira et al. 2010; Santana et al. 2010; Souza 2012; Souza-Silva \& Ferreira 2009; Souza-Silva et al. 2011a,b; Zampaulo 2010; Zeppelini Filho et al. 2003; Fundação Estadual do Estado de São Paulo 2010a,b,c,d). The average richness of those studies is 50 species $( \pm 20)$. In the present study the average found was higher than the general average for the Brazilian caves, but it is within the standard deviation. Therefore, the study area cannot be highlithed as one of the richer areas concerning cave fauna in Brazil. However, thirteen caves deserve prominence, because they present richness above average, plus the standard deviation, when compared to the other regions of Brazil (Tab. 2).

Regarding the troglobitic species, the distribution restricted to one or few caves, added to their potential low reproduction rate, make those organisms sensitive to alterations in the environment (Culver \& Pipan 2009). Accordingly, they become an important tool for cave conservation (Elliott 2007; Borges et al. 2012). In the present study the troglobitis species presented a high degree of endemism and all of the caves that shelter troglobites possess at least one endemic species. Therefore, even if not being classified as the most vulnerable, these caves should be inserted in future conservation plans.

\section{THREATS AND CONSERVATION STATUS OF THE AREA}

The inadequate use of the land for agricultural activities, expansion of cities, surface and subterranean water use, mining activities, among others, have been the main threats imposed to the karstic areas (Watson 1997).

In the study region the main threat is the removal of forests for creation of pastures. Locally endemic cave species can become extinct if the surrounding area is deforested (Reboleira et al. 2011). Furthermore, the removal of the vegetation from the cave entrance surroundings can reduce the resource contribution and alter the environment in these areas, for instance, changing the local temperature and humidity/moisture. The entrances work as ecotones and they shelter a wide diversity of species that depend on the resource imported from the external environment (Prous et al. 2004).

The main potential threat for the caves of the studied region is the pollution of their water bodies, a fact 
that can result in severe alterations to the environment and cave fauna. As an example, the agricultural practices carried out in the surroundings of the Tumbling Creek cave, (Missouri, USA), are affecting the water quality and they may be decreasing the population of aquatic species sensitive to these changes (Antrobia culveri) (Neill et al. 2004).

Although the region, as are all the karstic areas of the world, is subject to impacts of anthropic origin, there are still places that are preserved, as is the case of the northern portion of the region, like the municipal district of Arinos. The caves of this municipal district are considerably preserved if compared to other caves of the study. A good example is the Lapa da Capa, where no visible impact was found, to the surroundings as well as to the interior the cavity. Nevertheless, the area is inserted in the Cerrado biome, known for high diversity and constant threats (Myers et al. 2000), always in need of conservation actions.

\section{LEGAL PROTECTION AND PUBLIC EDUCATION}

The lack of laws specifically dedicated to the karst is very common all over the world. Even when the legislation considers these environments, the potential benefits do not indeed exists, mainly due to the lack of enforcement on the part of the authorities (Parise \& Gunn 2007).

Throughout the world, there are only few countries that possess some type of specific legislation for cave protection; some that do for instance, are the United States, France, Slovenia, Australia and Brazil (Tercafs 1992; Kepa 2001; Restificar et al. 2006; Ferreira et al. 2007). There are examples of legally protected caves and areas, as is the case of regions considered as World Heritage sites due to the characteristics of their karstic landscapes (Williams 2008). However, karstic areas and caves have been sometimes protected in an indirect way, mainly by the establishment of reserves for reasons that do not include the importance of their karstic characteristics, as in the case of Central American countries (Day 1996; Kueny \& Day 2002) and some countries of Southeast Asian (Day \& Urich 2000).

Brazil is the only country that has an agency devoted specifically to the study, protection and management of caves, which comprises the Centro Nacional de Pesquisa e Conservação de Cavernas (CECAV) (National Cave Research and Conservation Center (CECAV). Historically, the Brazilian caves could not be destroyed for being patrimonies of the Union (Federal Constitution 1998; Decree 99556/1990). However in 2008, the caves started to be susceptible to supression (Decree $6640 / 2008$ ), as long as they were previously studied during the enterprise licensing process. During the study the caves should be classified, according to their relevance, as maximum, high, medium and low, according to criteria proposed in the Instruction Normative Number 2 of 2009. Caves with maximum relevance are not able, under any circumstances, to be suppressed, and caves included in the other categories are susceptible to irreversible alterations, including suppression.

Such a decree has been severely criticized and considered a setback for cave conservation in the country (Figueiredo et al. 2010). However, the rigidity of the previous law caused, in cases of strong social and economical demand, caves' suppression (Auler 2006), many times without there being previous study.

It is important to point out that protection based only in laws is not enough. Real and efficient protection should count on the support of the population and a continuous program of public education regarding the protection of resources (Watson 1997). Furthermore, the appropriate use of the land can increase the sustainable development of the economy in these areas (Linhua 1999).

\section{CAVES CONSERVATION IN THE WORLD}

Different strategies for conservation of caves and karstic areas have been used all over the world. Indices have been used to evaluate the impact degree and threats, seeking to identify karstic areas most threatened and/or that deserve priority attention for conservation strategies (Elliott 2007; Van Beynen \& Townsend 2005; 2012).

Van Beynen \& Townsend (2005) created a karstic area disturbance index with different indicators, including the subterranean fauna, which has been used in works that seek to propose priority areas for conservation (Calò \& Parise 2006; Van Beynen et al. 2007; Borges et al. 2012). Van Beynen \& Townsend (2005), however, affirmed that the selection of individual species as indicators would be problematic because of disagreements about which species to use. Therefore, only in Borges et al. (2012) was the biological component used as indicator, based on the troglobite richness, endemism and rarity. Recently a karst sustainability index was created (KSI) (Van Beynen \& Townsend 2012). This index is based on indicators that incorporate measurements of the three resources use domains: the social, the environmental and the economic.

The species distribution was used to identify places with threatened species and to propose conservation priorities by Culver et al. (2000) and Lewis et al. (2003), both in areas of the United States, and by Ferreira et al. (2007) in karstic areas of France.

Elliott (2007) used the species richness, troglobite richness and endemism as indicators for an index used to rank biodiversity relevance of caves in Missouri, Unit- 
ed States, for conservation plans. Such index uses the expression $\mathrm{B}=\mathrm{SR} \times \mathrm{T} \times \mathrm{SE}$, where, $\mathrm{B}$ is: biodiversity, $\mathrm{SR}$ : species richness, T: troglobites richness, SE: local endemism.

In several regions of Brazil, studies are using methodologies similar to those used in this work to propose priority areas and caves for conservation (Souza-Silva 2008; Zampaulo 2010; Bento 2011; Souza 2012). Good results have been obtained, as is the case of the creation of the Parque Nacional da Furna Feia, in the state of Rio Grande do Norte, where 36\% (205 caves) of all of the caves known to the state are inserted and legally protected. That area had been pointed out by Bento (2011) as priority for conservation in the State of Rio Grande do Norte in function of his work that used the same methodology as employed here.

\section{CONSERVATION ACTIONS}

Although protected areas, in themselves, do not guarantee the preservation of nature, they are fundamental tools, separating elements of the biodiversity from the processes that threaten Nature (Margules \& Pressey 2000). In karstic landscapes the creation of buffer zones in between the preservation area and the neighboring lands is important, reducing the influences and consequences of environmental damage to the adjacent lands (Barany-Kevei 1999).

In Brazil, the creation of reserves faces serious problems. Caves inserted in preservation areas suffer visitation impacts, as for instance, trampling, garbage and speleothem depredation, among others (Lobo 2008; Souza-Silva \& Ferreira 2009). Thus, the creation of nature reserves for the protection of caves or cave species should be very well appraised and elaborated, besides possessing an effective site management plan, integrating scientists, managers and tourism professionals, besides specific studies on each cave used for tourist visitation (Lobo et al. 2013).

Although direct impacts (e.g. mining) are the most worrisome, because they can cause immediate losses, other impacts can create countless problems for the fauna, although over the long term. The pollution of water bodies is an example. Karstic land possess discontinuities through which potential pollutants can be transport- ed to remote locations, such as springs and caves with groundwater and rivers (Parise \& Gunn 2007). Therefore, to reduce the exploration and water pollution on karstic land would be important for the maintenance of caves that possess groundwater and rivers (De Waele \& Follesa 2003).

\section{FINAL REMARKS}

To study the subterranean biodiversity in the maximum number of caves in the Cerrado is of addition importance, because it is a highly diverse environment and under constant threat (Myers et al. 2000). As such, the present study presented results that can aid conservation actions in a little studied region in this biome. Furthermore, other karstic areas in the São Francisco river basin should be investigated regarding their conservation priority, providing subsidies for the National Action Plan for conservation of caves and cave fauna of that region.

Caves and karstic areas are being affected all over the world, mainly by anthropic action. Although probable, it is impossible to determine if such impacts have been causing the loss of species in these environments, mainly through lack of information of the primary characteristics of the communities prior to the impacts.

Even facing the difficulty of quantifying the cave biodiversity loss before alterations in the environment, it is certain that loss exists. Although the impacts that cause irreversible alterations in the caves, such as mining, are the main targets for environmentalists, others are also highly troubling.

In the study region, as well as throughout the world, the removal of forests appears as one of the most disturbing alterations, not only for the epigean biodiversity, but also for the subterranean. Cave species depend, largely, on the importation of resources from the external environment (Culver 1982) and the removal of forests can reduce that importation.

Another important fact is that tropical forests shelter a great diversity of species and they are subject to various impacts of anthropic origin, mainly linked to agricultural activities, that provoke, in almost all cases, high epigean biodiversity loss (Gibson et al. 2011). Once the epigean biodiversity is decreased, possibly fewer species will be using the cave environment.

\section{ACKNOWLEDGMENTS}

To the Fundação de Amparo à Pesquisa e Extensão de Minas Gerais (FAPEMIG) for financial support, project APQ-01854-09. To friends of the Grupo de Estudos em
Ecologia Subterrânea da Universidade Federal de Lavras. To Espeleo Grupo de Brasília for information about the caves in the region. 


\section{REFERENCES}

Auler, A. S., 2006: Relevância de cavidades naturais subterrâneas: contextualização, impactos ambientais e aspectos jurídicos.- Ministério de Minas e Energia (MME), pp. 166, Brasília.

Australian Speleological Federation, 2010: Minimal Impact Caving Code (MICC).- [Online] Available from: http://www.caves.org.au/downloads/ MICC2010.pdf [Accessed 3rd October 2012].

Australian Speleological Federation. Minimum Impact Code of Ethics for Scientific Investigation in Caves and Karst (Science MIC), 3pp, 2010. Available from: http://www.caves.org.au/downloads/ScienceCodeJul2010.pdf [Accessed 3rd October 2012].

Balák, I. Janèo, J., Stefka, L. \& P. Bosák, 1999: Agriculture and nature conservation in the Moravian karst (Czech Republic).- International Journal of Speleology, 28B, 71-88.

Barany-Kevei, I., 1999: Impacts of agricultural land use on some Hungarian karst regions.- International Journal of Speleology, 28B, 89-98.

Bento, D.M., 2011: Diversidade de invertebrados em cavernas calcárias do oeste potiguar: subsídios para determinação de áreas prioritárias para conservação. M.D. Thesis. Universidade Federal do Rio Grande do Norte, pp. 160.

Bernardi, L.F.O., Pellegrini, T.G., Taylor, E.L.S. \& R.L. Ferreira, 2012: Aspectos ecológicos de uma caverna granítica no sul de Minas Gerais.- Espeleo-Tema, 23, 5-12.

Borges, P.A.V., Cardoso, P., Amorim, I.R., Pereira, F., Constância, J.P., Nunes, J.C., Barcelos, P., Costa, P., Gabriel, R. \& M.L. Dapkevicius, 2012: Volcanic caves: priorities for conserving the Azorean endemic troglobiont species.- International Journal of Speleology, 41, 101-111.

Calò, F. \& M. Parise, 2006: Evaluating the human disturbance to karst environments in southern Italy.- Acta Carsologica, 35, 47-56.

Cavalcanti, L.F., Lima, M.F., Medeiros, R.C.S. \& I. Meguerditchian, 2012: Plano de ação nacional para a conservação do patrimônio espeleológico nas áreas cársticas da Bacia do Rio São Francisco, (Série Espécies Ameaçadas, 27).- Instituto Chico Mendes de Conservação da Biodiversidade, pp. 140, Brasília.

Constituição da República Federativa do Brasil, 1988: [Online] Available from: http://www.planalto.gov. br/ccivil_03/constituicao/ConstituicaoCompilado. htm [Accessed $3^{\text {rd }}$ September 2012].
Cordeiro, L.M., 2008: Fauna cavernícola da Serra da Bodoquena: revisão bibliográfica e um estudo de ecologia de comunidades.- M.D. Thesis. Universidade Federal do Mato Grosso do Sul, pp. 119.

Culver, D.C. \& H. Wilkens, 2000: Critical review of relevant theories of the evolution of subterranean animals.- In: Wilkens, H. et al. (eds.) Ecosystems of the World Vol30: Subterranean Ecossystems. Elsevier Press, p. 381-397, Amsterdam.

Culver, D.C. \& T. Pipan, 2009: The biology of caves and other subterranean habitats.- Oxford University Press, pp. 254, Oxford.

Culver, D.C., 1982: Cave life: Evolution and Ecology.Harvard University Press, pp. 189, Massachussets and London.

Culver, D.C., M.D. L.L., Christman M.C. \& H.H. Hobbs, 2000: Obligate cave fauna of the 48 contiguous United States.- Conservation Biology, 14, 386-401.

Day, M. \& P. Urich, 2000: An assessment of protected karst landscapes in Southeast Asia.- Cave and Karst Science, 27, 61-70.

Day, M.J., 1996: Conservation of Karst in Belize.- Journal of Cave and Karst Studies, 58, 139-144.

De Waele, J. \& R. Follesa, 2003: Human impact on karst: the example of Lusaka (Zambia).- International Journal of Speleology, 32, 71-83.

Decreto No 6.640, 2008: [Online] Available from: http://www.planalto.gov.br/ccivil_03/_Ato20072010/2008/Decreto/D6640.html [Accessed $3^{\text {rd }}$ September 2012].

Decreto No 99.556, 1990: [Online] Available from: http:// www2.camara.gov.br/legin/fed/decret/1990/decreto-99556-1-outubro-1990-339026-normaatualizada-pe.html [Accessed 3rd September 2012].

Derraik, J.G., Closs, G.P., Dickinson, K.J., Sirvid, P., Barratt, B.I.P. \& B.H. Patrick, 2002: Arthropod Morphospecies versus Taxonomic Species: a Case Study with Araneae, Coleoptera, and Lepidoptera.- Conservation Biology, 16, 1015-1023.

Derraik, J. G., Early, J.W., Closs, G.P. \& K.J. Dickinson, 2010: Morphospecies and taxonomic species comparison for Hymenoptera.- Journal of Insect Science, $10,1-7$.

Elliott, W.R., 2004: Protecting caves and cave life.- In: Culver, D.C. \& W.B. White, (eds.). Encyclopedia of caves. Elsevier Academic Press, pp. 458-467, San Diego. 
Elliott, W.R., 2000: Conservation of the North American cave and karst biota.- In: Wilkens, H. et al. (eds.) Ecosystems of the World Vol30: Subterranean Ecossystems. Elsevier Press, pp. 665-689, Amsterdam.

Elliott, W.R., 2007: Zoogeography and biodiversity of Missouri caves and karst.- Journal of Cave and Karst Studies, 69, 135-162.

Ferreira, D., Malard F., Dole-Olivier, M.J. \& J. Gibert, 2007: Obligate groundwater fauna of France: diversity patterns and conservation implications.- Biodiversity and Conservation, 16, 567-596.

Ferreira, R. L., 2004: A medida da complexidade ecológica e suas aplicações na conservação e manejo de ecossistemas subterrâneos.- PhD Thesis. Universidade Federal de Minas Gerais, pp. 158.

Ferreira, R.L. \& L.C.S. Horta, 2001: Natural and human impacts on invertebrate communities in brazilian caves.- Revista Brasileira de Biologia 61, 7-17.

Ferreira, R.L., Bernardi, L.F.O., M. Souza-Silva, 2009: Caracterização dos ecossistemas das Grutas Aroê Jari, Kiogo Brado e Lago Azul (Chapada dos Guimarães, MT): Subsídios para o turismo nestas cavidades.Revista de Biologia e Ciências da Terra, 9, 41-58.

Ferreira, R.L., Gomes, F.T.M.C. \& M. Souza-Silva, 2008: Uso da cartilha "Aventura da vida nas cavernas" como ferramenta de educação nas atividades de turismo em paisagens cársticas.- Pesquisas em Turismo e Paisagens Cársticas, 1, 139-158.

Ferreira, R.L., Prous, X., Bernardi, L.F.O. \& M. SouzaSilva, 2010: Fauna subterrânea do estado do Rio Grande do Norte: caracterização e impactos.- Revista brasileira de espeleologia, 1, p. 25-51

Figueiredo, L.A.V., Rasteiro, M.A. \& P.C. Rodrigues, 2010: Legislação para a proteção do patrimônio espeleológico brasileiro: mudanças, conflitos e o papel da sociedade civil.- Espeleo-Tema, 21, 49-65.

Fundação Florestal do Estado de São Paulo, 2010a: Plano de manejo espeleológico: Caverna do Diabo.- [Online] Available from: http://www.ambiente.sp.gov. $\mathrm{br} /$ fundacaoflorestal/planos-de-manejo/planos-demanejo-planos-espeleologicos (Accessed $1^{\text {st }}$ November 2012).

Fundação Florestal do Estado de São Paulo, 2010b: Plano de manejo espeleológico: Gruta da Capelinha.[Online] Available from: http://www.ambiente. sp.gov.br/fundacaoflorestal/planos-de-manejo/planos-de-manejo-planos-espeleologicos/ (Accessed 1st November 2012).
Fundação Florestal do Estado de São Paulo, 2010c: Plano de manejo espeleológico: Parque Estadual Turístico do Alto Ribeira (PETAR).- [Online] Available from: http://www.ambiente.sp.gov.br/fundacaoflorestal/ planos-de-manejo/planos-de-manejo-planos-espeleologicos/ (Accessed 1st November 2012).

Fundação Florestal do Estado de São Paulo, 2010d: Plano de manejo espeleológico: Parque Estadual Intervales.- [Online] Available from: http://www.ambiente. sp.gov.br/fundacaoflorestal/planos-de-manejo/planos-de-manejo-planos-espeleologicos/ (Accessed $1^{\text {st }}$ November 2012).

Gibert, J. \& L. Deharveng, 2002: Subterranean Ecosystems: A Truncated Functional Biodiversity.- BioScience, 52, 473-481.

Gibson, L., Lee, T.M., Koh, L.P., Brook, B.W., Gardner, T.A., Barlow, J., Peres, C.A., Bradshaw, C.J.A., Laurance, W.F., Lovejoy, T.E. \& N.S. Sodhi, 2001: Primary forests are irreplaceable for sustaining tropical biodiversity.- Nature, 478, 378-383.

Gillieson, D. \& M. Thurgate, 1999: Karst and agriculture in Australia.- International Journal of Speleology, 28B, 149-168.

Gunn, J., Hardwick, P. \& P.J. Wood, 2000: The invertebrate community of the Peak-Speedwell cave system, Derbyshire, England - pressures and considerations for conservation management.- Aquatic Conservation: Marine And Freshwater Ecosystems, 10, 353-369.

Huppop, K., 2012: Adaptation to low food.- In: White, W.B. \& D.C. Culver (eds) Encyclopedia of Caves, $2^{\text {nd }}$ edition, Academic Press, p. 1-9, New York.

Instrução Normativa No 2, 2009: [Online] Available from: http://www.icmbio.gov.br/cecav/images/ download/IN\%2002_MMA_Comentada.pdf (Accessed 3rd Octuber 2012).

Kepa, T., 2001: Karst conservation in Slovenia.- Acta carsologica, 30, 143-164.

Kueny, J.A. \& M.J. Day, 2002: Designation of protected karstlands in Central America: a regional assessment.- Journal of Cave and Karst Studies, 64, 165174.

Lewis, J.J., Moss, P.H., Tecic, D. \& M.E. Nelson, 2003: A conservation focused inventory of subterranean invertebrates of the southwest Illinois karst.- Journal of Cave and Karst Studies, 65, 9-21.

Linhua, S., 1999: Sustainable development of agriculture in karst areas, South China.- International Journal of Speleology, 28B, 139-148. 
Lobo, H.A.S., 2008: Ecoturismo e percepção de impactos socioambientais sob a ótica dos turistas no Parque Estadual Turístico do Alto Ribeira - PETAR.- Pesquisas em Turismo e Paisagens Cársticas, 1, 67-75.

Lobo, H.A.S., Trajano, E., Marinho, M.A., Bichuette, M.E., Scaleante, J.A.B., Scaleante, O.A.F., Rocha, B.N. \& F.V. Laterza, 2013: Projection of tourist scenarios onto fragility maps: Framework for determination of provisional tourist carrying capacity in a Brazilian show cave.- Tourism Management, 35, 234-243.

Margules, C.R. \& R.L. Pressey, 2000: Systematic conservation planning.- Nature, 405, 243-253.

Myers, N., Mittermeier, R.A., Mittermeier, C.G., Fonseca G.A.B. \& J. Kent, 2000: Biodiversity hotspots for conservation priorities.- Nature, 403, 853-858.

Neill, H., Gutiérrez, M. \& T. Aley, 2004: Influences of agricultural practices on water quality of Tumbling Creek cave stream in Taney County, Missouri.- Environmental Geology, 45, 550-559.

Oliver, I. \& A.J. Beattie, 1996: Invertebrate morphoespecies as surrogates for species: a case study.- Conservation Biology. 1, 99-109.

Parise, M. \& J. Gunn, 2007: Natural and anthropogenic hazards in karst areas: an introduction.- Geological Society of London: Special Publications, 279, 1-3

Parise, M. \& V. Pascali, 2003: Surface and subsurface environmental degradation in the karst of Apulia (southern Italy).- Environmental Geology, 44, 247256.

Pellegrini, T.G. \& R.L. Ferreira, 2012b: Management in a neotropical show cave: planning for invertebrates conservation.- International Journal of Speleology, 41, 361-368.

Pellegrini, T.G. \& R.L. Ferreira,2012a: Sampling effort in mite communities associated with cave bat guano.Speleobiology Notes, 4, 10-16.

Prous, X., Ferreira, R.L. \& R.P. Martins, 2004: Ecótone delimitation: epigean-hypogean transition in cave ecosystems.- Austral Ecology, 29, 374-382.

Reboleira A.S., Borges P.A.V., Gonçalves, F., Serrano A.R.M. \& P. Oromí, 2011: The subterranean fauna of a biodiversity hotspot region - Portugal: an overview and its conservation.- International Journal of Speleology, 40, 23-37.

Restificar, S.D.F., Day, M.J. \& P.B. Urich, 2006: Protection of karst in the Philippines.- Acta Carsologica, 35, 121-130.
Santana, M.E.V., Souto, L.S. \& M.A.T. Dantas, 2010: Diversidade de invertebrados cavernícolas na Toca da Raposa (Simão Dias - Sergipe): o papel do recurso alimentar e métodos de amostragem.- Scientia Plena, 6, 1-8.

Souza, M.F.V.R. \& R.L. Ferreira, 2012: Eukoenenia virgemdalapa (Palpigradi: Eukoeneniidae): a new troglobitic palpigrade from Brazil.- Zootaxa, 3295, 59-64.

Souza, M.F.V.R., 2012: Diversidade de invertebrados subterrâneos da região de Cordisburgo, Minas Gerais: subsídios para definição de cavernas prioritárias para conservação e para o manejo biológico de cavidades turísticas.- M.D. Thesis. Universidade Federal de Lavras, pp. 149.

Souza-Silva, M. \& R.L. Ferreira, 2009: Caracterização ecológica de algumas cavernas do Parque Nacional de Ubajara (Ceará) com considerações sobre o turismo nestas cavidades.- Revista de Biologia e Ciências da Terra, 9, 59-71.

Souza-Silva, M., 2008: Ecologia e conservação das comunidades de invertebrados cavernícolas na Mata Atlântica Brasileira.- PhD thesis. Universidade Federal de Minas Gerais, pp. 211.

Souza-Silva, M., Bernardi, L.F.O., Martins, R.P. \& R.L. Ferreira, 2012: Transport and consumption of organic detritus in a neotropical limestone cave.- Acta Carsologica, 41, 139-150.

Souza-Silva, M., Martins, R.P. \& R.L. Ferreira, 2011a: Cave lithology determining the structure of the invertebrate communities in the Brazilian Atlantic Rain Forest.- Biodiversity Conservation, 20, 17131729.

Souza-Silva, M., Nicolau, J.C. \& R.L. Ferreira, 2011b: Comunidades de invertebrados terrestres de três cavernas quartzíticas no Vale do Mandembe, Luminárias, MG. Espeleo-Tema.- 22, 79-91.

Tercafs, R., 1992: The Protection of the subterranean environment: conservation principles and management tools.- In Camacho, A. (eds.) The Natural history of bioespeleology. Museo Nacional de Ciencias Naturales, pp. 485-522, Madrid.

Van Beynen, P. \& K. Townsend, 2005: A Disturbance index for karst environments.- Environmental Management, 1, 101-116.

Van Beynen, P., Brinkmann, R. \& K. Van Beynen, 2012: A sustainability index for karst environments.Journal of Cave and Karst Studies, 74, 221-234.

Van Beynen, P., Feliciano, N., North, L. \& K. Townsend, 2007: Application of a Karst Disturbance Index in Hillsborough County, Florida.- Environmental Manage, 39, 261-277. 
Ward, D.F \& M.C. Stanley, 2004: The value of RTUs and parataxonomy versus taxonomic species.- New Zealand Entomologist, 27, 3-9.

Watson, J., Hamilton-Smith, E., Gillieson, D. \& K. Kiernan, 1997: Guidelines for cave and karst protection: IUCN, pp. 63, Gland/Cambridge.

Weinstein, P. \& D. Slaney, 1995: Invertebrate faunal survey of Rope Ladder cave, Northern Queensland: a comparative study of sampling methods.- Journal of Australian Entomological Society, 34, 233-236.

Williams, P., 2008: World Heritage Caves and Karst.IUCN, pp. 57, Gland.
Zampaulo, R.A., 2010: Diversidade de invertebrados na província espeleológica de Arcos, Pains, Doresópolis (MG): Subsídios para a determinação de áreas prioritárias para a conservação.- M.D. thesis. Universidade Federal de Lavras, pp. 190.

Zeppelini Filho, D., Ribeiro, A.C., Ribeiro, G.C., Fracasso, M.P.A., Pavani, M.M., Oliveira, O.M.P., Oliveira, S.A. \& A.C. Marques, 2003: Faunistic survey of sandstone caves from Altinópolis region, São Paulo State, Brazil.- Papéis Avulsos de Zoologia, 43, 93-99. 